\title{
Disposisi Matematis Siswa pada Penerapan Etnomatematika dalam Pembelajaran Matematika
}

\author{
Nur Islamiati ${ }^{1 *}$, Nasruddin $^{1)}$ \\ ${ }^{1)}$ Sekolah Tinggi Kegurun dan Ilmu Pendidikan Al-Amin Dompu \\ *nurislamiati8@gmail.com
}

Abstrak: Penelitian ini bertujuan mendeskripsikan disposisi matematis siswa pada penerapan etnomtematika pada pembelajaran matematika. Pendekatan yang digunakan adalah kualitatif dan kuantitatif dengan jenis deskriptif. Subjek penelitian ini yaitu 1 guru pendidikan matematika dan 28 siswa SMPN 3 Sape. Data diperoleh melalui wawancara dan angket jenis Skala Likert. Hasil penelitian menunjukan bahwa pada penerapan etnomatematika dapat memberikan pengaruh positif terhadap domain afektif siswa. Domain afektif yang dimaksud dalam penelitian ini adalah yaitu disposisi matematis. Hasil penelitian berdasarkan wawancara dengan guru matematika menunjukan bahwa dengan menerapkan etnomatematika dalam mempelajari matematika dapat meningkatkan minat dan kepercayaan diri siswa dalam belajar karena pendekatan tersebut telah dikenal baik oleh siswa sebab berkaitan dengan budaya dan dikehidupan sehari-hari siswa. Hal tersebut didukung dengan hasil analisis angket disposisi matematis yang dilihat dari beberapa apek yaitu: 1) rasa percaya diri dalam pembelajaran matematika. Aspek ini memperoleh skor rata-rata sebesar 2,48 dengan kategori baik yang menunjukan bahwa siswa merasa percaya diri dalam belajar matematika dengan menggunakan pendekatan etnomatematika. 2) kegigihan dan ketekunan dalam pembelajaran matematika. Aspek ini memperoleh rata-rata skor 2,35 dan kategori baik yang menunjukan bahwa siswa setuju dengan menggunakan pendekatan etnomatemtika mendorong siswa untuk lebih gigih dan tekun dalam belajar matematika

Kata Kunci: Disposisi Matematis, Etnomatematika, Matematika

\section{Pendahuluan}

Pelajaran matematika diberikan kepada peserta didik adalah untuk meningkatkan mutu dan kualitas pendidikan di Indonesia (Rostika \& Junita, 2017). Matematika adalah mata pelajaran yang cukup penting untuk digunakan dalam kehidupan sehari-hari yang dikarenakan banyak terdapat persoalan dalam kehidupan nyata yang tak terlepas dari perhitungan matematika yang melibatkan proses analisis, perhitungan dan kemampuan mental lainnya (Rattanatumma, 2016; Siniguian, 2017). Dalam kurikulum pendidikan Nasional, mewajibkan matematika sebagai salah satu mata pelajaran yang diberikan kepada peserta didik (Ariawan \& Nufus, 2017).

Matematika adalah pengetahuan yang melekat dalam aktivitas kehidupan, di mana setiap aktivitas tidak dapat dipisahkan dari aktivitas matematika (Muhtadi, Sukirwan, Warsito, \& Prahmana, 2017; Soraya, Cahyana, Sumantri, \& Adiansha, 2018). Berbagai tempat seperti di pasar, di ladang atau berbagai tempat aktivitas manusia ilmu matematika selalu hadir baik disadari ataupun tidak disadari oleh masyarakat. Dengan kata lain, bahwa matematika sangat dekat dengan budaya dalam konteks perilaku atau kebiasaan yang telah ada sejak zaman kuno dan dilakukan secara turun-temurun (Muhtadi et al., 2017). Hal tersebut menunjukan bahwa matematika merupakan mata pembelajaran yang perlu diajarkan pada peserta didik mulai dari SD sampai perguruan tinggi (Abdullah, 2017; Permana \& Adiansha, 2019).

Rendahnya kemampuan peserta didik di bidang matematika bukan hal yang baru karena peserta didik beranggapan bahwa pelajaran matematika adalah pelajaran yang sulit (Abdullah, 2017). Hal ini terdapat berbagai berbagai kesulitan dan tantangan seperti disposisi rendah untuk belajar matematika (Fouze \& Amit, 2018). Disposisi matematis berkaitan dengan bagaimana siswa memandang dan menyelesaikan masalah; apakah siswa percaya diri, tekun, berminat, dan berpikir terbuka untuk mengeksplorasi berbagai alternatif strategi penyelesaian masalah (Suharsono, 2015). Disposisi matematis merupakan salah satu faktor penting penunjang 
keberhasilan belajar matematika siswa akan tetapi anggapan buruk siswa terhadap matematika mengakibatkan disposisi matematis siswa dalam belajar matematika menjadi kurang (Nopriana, 2015).

Disposisi matematis yang tinggi memberikan pengaruh positif terhadap kemampuan pemecahan masalah matematika siswa (Kusmaryono \& Suyitno, 2016). Kurangnya kemampun disposisi matematis siswa mengakibatkan kesulitan dalam memahami dan memahami konsep-konsep matematika yang kompleks, perhatian dan konsentrasi di kelas, proses belajar matematika yang tidak menyenangkan yang berdampak negatif terhadap prestasi akademik siswa (Fouze \& Amit, 2018; Kusmaryono \& Suyitno, 2016). Hal ini mungkin menjadi salah satu alasan tidak konsistennya pendidik dalam memberikan pembelajaran di sekolah, yang tidak dapat memanfaatkan lingkungan lokal (Abdullah, 2017).

Beberapa cara yang telah digunakan oleh peneliti untuk mengatasi hal yang berkaitan dengan disposisi matematis adalah dengan menggunakan media pembelajaran, sumber belajar ataupun dengan pendekatan pembelajaran yang relevan. Salah satu cara yang digunakan untuk mengatasi masalah tersebut adalah dengan menerapkan pembelajaran yang berbasis pendekatan etnomatematika (Abdullah, 2017; Amor et al., 2016; Nusantara \& Rahardjo, 2017). Ethnomathematics adalah hubungan antara budaya dan matematika (Amor et al., 2016; Farokhah, Arisetyawan, \& Jupri, 2017). Ethnomathematics adalah bidang studi yang memanfaatkan budaya untuk memahami, mengartikulasikan, menemukan konsep dan praktik dalam mempelajari matematika (Amor et al., 2016). Pendapat tersebut didukung oleh (Farokhah et al., 2017; Nusantara \& Rahardjo, 2017) ethnomathematics adalah sebuah konsep untuk meningkatkan pengetahuan tentang perkembangan matematika dengan memanfaatkan berbagai budaya di seluruh dunia. Pernyataan lain mengungkapkan bahwa ethnomathematics adalah cara di mana orang-orang dari beragam budaya ketika menggunakan matematika dalam kehidupan sehari-hari (Maryati \& Pratiwi, 2019).

Penelitian yang dilakukan oleh (Astuningtyas, Wulandari, \& Farahsanti, 2018) menunjukan kegiatan pembelajaran menggunakan penerapan etnomatematika mendapat nilai problem solving yang cukup memuaskan dibandingkan dengan pembelajaran menggunakan proses biasa. Hasil penelitian tersebut didukung dengan hasil penelitian studi kasus yang dilakukan oleh (Amor et al., 2016) yang diperoleh menggunakan angket pada siswa dengan hasil dimana siswa kelas 5 sekolah dasar di Cipatujah merasa bahwa konsep matematika yang diajarkan di kelas tidak terkait dengan kehidupan sehari-hari (etnomatematika) dan itu membuat mereka berpikir bahwa matematika tidak menarik (walaupun ada yang mendapat nilai bagus dalam matematika) sehingga membuat mereka merasa bosan. (Farokhah et al., 2017) melakukan penelitian memperoleh hasil dengan analisis data menggunakan uji-t diperoleh bahwa kemampuan komunikasi matematis siswa di kelas eksperimen dengan pembelajaran menggunakan pendekatan SAVI berbasis ethnomathematics lebih baik daripada siswa kelas kontrol yang mendapatkan pembelajaran menggunakan pendekatan konvensional. Dalam memperoleh

pemahaman konsep pembelajaran matematika, kegiatan belajar mengajar perlu diadakannya nili-nilai kebudayaan (Putra \& Indriani, 2017). Dapat disimpulkan pembelajaran matematika berbasis pendekatan etnomatematika dapat membantu dalam mengatasi berbagai masalah dalam pembelajaran matematika khususnya disposisi matematis (Imswatama \& Lukman, 2018)

Paparan diatas yang menunjukan bahwa disposisi matematis memiliki peran penting dalam pembelajaran matematika, maka peneliti ingin meneliti bagaimana disposisi matematis siswa terhadap pembelajaran matematika dengan menggunkn pendekatan etnomatematika. Seperti yang telah diketahui bahwa diperlukannya disposisi matematis untuk mengembangkan berbagai kemampuan siswa dalam metamtika (Nopriana, 2015) dan etnomatematika dalam membantu siswa untuk memhmi konsep matematika (Putra \& Indriani, 2017). Berdasarkan penjelasan diatas yang menjadi tujuan pada penelitian ini adalah untuk mendeskripsikan disposisi matematis siswa pada penerpan etnomtematika pada pembelajarn matematika.

\section{Metode}

Penelitian menggunakan pendekatan kuantitatif dan kualitatif yang berjenis deskriptif. Subjek dalam penelitian adalah seorang guru sekolah pada bidang matematika dan 28 murid di SMPN 3 Sape. Teknik pengumpulan data menggunakan wawancara dan kuisioner atau angket. Wawancara ditujukan kepada seorang guru matematika yang melakukan kegiatan belajar mengajar menggunakan pembelajaran berbasis etnomatematika. Hal ini dilakukan untuk memperoleh informasi mendalam tentang pembelajaran matematika dengan menerapkan etnomatematika dan panilaian guru terhadap siswa terkait dengan disposisi matematis 
siswa, wawancara yang digunakan merupakan wawancara tidak terstruktur dimana peneliti melakukan wawancara terbuka dengan mengajukan pertnyaan yang berkaitan dengan objek penelitian. Angket dengan jenis skala likert terdapat beberapa opsi jawaban yang memiliki skor pada setiap pilihan yaitu "sangan setuju" deangan skor empat, "setuju" dengan skor tiga, "tidak setuju" dengan skor 2, dan "sangat tidak setuju" dengan perolehan skor satu. Penyebaran angket ditujukan kepada dan dilaksanakan guna mendapatkan data tentang bagaimana disposisi matematis siswa pada penerapan pendekatan etnomatematika dalam pembelajaran matematika. Analisis data dilakukan dengan teknik interactive analysis models (reduksi data, penyajian data, dan penarikan kesimpulan). Selain data yang diperoleh juga di analisis secara statistik deskriptif (perhitungan persentase, dan nilai rata-rata).

Tabel 1. Distribusi Jumlah Item Angket

\begin{tabular}{clcc}
\hline \multirow{2}{*}{ No } & \multicolumn{1}{c}{ Aspek } & \multicolumn{2}{c}{ Jumlah Item } \\
\cline { 3 - 4 } & & + & - \\
\hline 1 & Rasa percaya diri dalam pembelajaran matematika & 3 & 2 \\
2 & Kegigihan dan Ketekunan dalam pembelajaran matematika & 3 & 2 \\
\hline
\end{tabular}

\section{Hasil dan Pembahasan}

Wawancara terlebih dahulu dilakukan kepada guru matematika untuk memperoleh informasi mendalam tentang pembelajaran matematika menggunakan pendektan etnomatematika Langkah selanjutnya yaitu memberikan angket berupa angket kepada siswa untuk memperoleh informasi mengenai disposisi matematis siswa terhadap pembelajaran matematika ketika menggunakan pendekatan etnomatematika.

\section{Perspektif Guru dalam Pembelajaran Matematika Menerapkan Pendekatan Etnomatematika}

Berdasarkan hasil wawancara dengan salah seorang guru matematika di SMPN 3 Sape diperoleh bahwa guru telah menerapkan pembelajaran matematika dengan pendekatan etnomatematika. Hal ini dikarenakan siswa kurang menyukai, minat dan merasa kesulitan dalam belajar maupun mengerjakan soal yang mengakibatkan pemahaman dan hasil belajar siswa menjadi rendah sedangkan pada kurikulum 2013 menekankan pada kemampuan matematika yang tinggi. Dikarenakan hal tersebut maka guru memilih berbagai cara yang dapat mengatasi hal tersebut yang salah satunya adalah dengan menerapkan pendekatan etnomtematika pada pembelajaran dengan alasan bahwasanya dengan mengaitkan budaya dan matematika mempu mengatasi masalah tersebut yang sebagai mana dijelaskan pada kutipan wawancara berikut.

$\mathrm{P}$ : Apakah anda pernah menerapkan pembelajaran matematika dengan pendekatan etnomatematika?

G : Sering saya gunakan Buk, kalau tidak seperti itu banyak siswa yang tidak paham materinya.

P : Bagaimanakah menurut Bapak ketika menerapkan pendekatan tersebut ketika pembelajaran matematika berlangsung?

G : Saya dan ibuk pasti tau kalau matematika itu penting dan sangat lekat dengn kehidupan masyarakat. Jadi saya mencoba juga untuk mengambil contoh-contoh dikehidupan sehari-hari saat belajar matematik. Alhamdulillhnya siswa-siswa saya mudah memahami materi.

P : Etnomatematika yng bagaimana yang telah Bapak terapkan untuk mempelajari konsep matematika?

G : Rumah Lengge untuk belajar bangun ruang dan datar, pernah saya praktik untu membawa sarung tenun untuk belajar luas. Dikelas saya juga bnyk orang yang tinggal di Bugis (pinggir pantai) jadi saya ambil contoh masalah harga-harga ikan.

P : Pengaruh positif seperti apa yang terlihat pada siswa menggunakan etnomatematika?

$\mathrm{G}$ : Siswa saya lebih paham meterinya, malah siswa saya lebih suka saat saya ksih soal-soal cerita dibandingkan yang rumus-rumus.

Berdasarkan kutipan wawancara diatas menunjukan bahwa guru menggunakan pendekatan etnomatematika dalam mempelajari matematika karena pendekatan tersebut telah dikenal baik oleh siswa sebab berkaitan dengan budaya dan dikehidupan sehari-hari siswa. Penerapan etnomatematika memberikan dampak positif terhadap pemahaman dan disposisi siswa terhadap metematika khususnya saat mengerjakan soal yang 
diberikan yang berkaitan dengan budaya ataupun etnomtematika. Sehingga etnomatemtika menjadi salah satu alternatif yang dapat digunakan.

\section{Disposisi Matematis Siswa Pada Penerapan Pendekatan Etnomtemtika}

Hasil penelitian disposisi matematis pada enerapan pendekatan etnomatematika diperoleh menggunakan angket tertutup dengan jenis skala likert. Pengukuran disposisi matematis siswa terdiri dari beberapa aspek antara lain: 1) Rasa percaya diri dalam pembelajaran matematika; dan 2) Gigih dan ulet dalam mengerjakan tugas matematika. Tabel berikut hasil analisis dari disposisi matematis siswa pada penerpan pendekatan etnomatematika pada pembelajaran matematika.

Tabel 2. Rasa percaya diri dalam pembelajaran matematika

\begin{tabular}{|c|c|c|c|c|c|c|}
\hline \multirow{2}{*}{ No } & \multirow{2}{*}{ Item } & \multicolumn{4}{|c|}{ Opsi } & \multirow{2}{*}{$\begin{array}{l}\text { Rata- } \\
\text { rata }\end{array}$} \\
\hline & & SS & $\mathrm{S}$ & TS & STS & \\
\hline \multirow[t]{2}{*}{1} & \multirow{2}{*}{$\begin{array}{l}\text { Saya yakin dapat memeroleh nilai yang } \\
\text { baik dalam matematika ketika } \\
\text { diberikan soal dengat etnomatematika }\end{array}$} & 2 & 20 & 3 & 3 & \multirow[b]{2}{*}{2,64} \\
\hline & & $7,14 \%$ & $71,48 \%$ & $10,71 \%$ & $10,71 \%$ & \\
\hline \multirow[t]{2}{*}{2} & \multirow{2}{*}{$\begin{array}{l}\text { Saya yakin mampu mengerjakan tugas } \\
\text { matematika berkaitan dengan } \\
\text { etnomatematika }\end{array}$} & 1 & 25 & 2 & 0 & \multirow[b]{2}{*}{2,96} \\
\hline & & $3,57 \%$ & $89,28 \%$ & $7,14 \%$ & $0 \%$ & \\
\hline \multirow[t]{2}{*}{3} & \multirow{2}{*}{$\begin{array}{l}\text { Saya yakin nilai matematika saya tetap } \\
\text { rendah meskipun saya telah belajar } \\
\text { keras }\end{array}$} & 0 & 1 & 23 & 4 & \multirow[b]{2}{*}{1,89} \\
\hline & & $0 \%$ & $3,57 \%$ & $82,14 \%$ & $14,28 \%$ & \\
\hline \multirow[t]{2}{*}{4} & \multirow{2}{*}{$\begin{array}{l}\text { Saya malu diketahui orang lain jika } \\
\text { memeroleh nilai jelek dalam } \\
\text { matematika }\end{array}$} & 0 & 0 & 26 & 2 & \multirow[b]{2}{*}{1,92} \\
\hline & & $0 \%$ & $0 \%$ & $92,85 \%$ & $7,14 \%$ & \\
\hline \multirow[t]{2}{*}{5} & \multirow{2}{*}{$\begin{array}{l}\text { Saya merasa senang dan termotivasi } \\
\text { ketika pelajaran matematika belajar } \\
\text { dengan pendekatan etnomatematika }\end{array}$} & 5 & 20 & 2 & 1 & \multirow[b]{2}{*}{3,03} \\
\hline & & $17,85 \%$ & $71,48 \%$ & $7,14 \%$ & $3,57 \%$ & \\
\hline & \multirow{2}{*}{ Rata-rata } & 1,6 & 13,2 & 11,2 & 2 & \multirow{2}{*}{2,48} \\
\hline & & $5,71 \%$ & $47,16 \%$ & $39,99 \%$ & $7,14 \%$ & \\
\hline
\end{tabular}

Tabel 3. Kegigihan dan Ketekunan dalam pembelajaran matematika

\begin{tabular}{|c|c|c|c|c|c|c|}
\hline \multirow{2}{*}{ No } & \multirow{2}{*}{ Item } & \multicolumn{4}{|c|}{ Opsi } & \multirow{2}{*}{$\begin{array}{l}\text { Rata- } \\
\text { rata }\end{array}$} \\
\hline & & SS & $S$ & $\mathrm{TS}$ & STS & \\
\hline \multirow[t]{2}{*}{6} & \multirow{2}{*}{$\begin{array}{l}\text { Saya belajar matematika ketika di } \\
\text { sekolah saja }\end{array}$} & 0 & 1 & 0 & 27 & \multirow[t]{2}{*}{1,07} \\
\hline & & $0 \%$ & $3,57 \%$ & $0 \%$ & $96,42 \%$ & \\
\hline \multirow[t]{2}{*}{7} & \multirow{2}{*}{$\begin{array}{l}\text { Saya senang mengerjakan soal-soal } \\
\text { latihan atau tes yang berkitan dengan } \\
\text { etnomatematika untuk memperdalam } \\
\text { pemahaman. }\end{array}$} & 2 & 24 & 1 & 1 & \multirow[t]{2}{*}{2,96} \\
\hline & & $7,14 \%$ & $85,71 \%$ & $3,57 \%$ & $3,57 \%$ & \\
\hline \multirow[t]{2}{*}{8} & \multirow{2}{*}{$\begin{array}{l}\text { Saya mengulang kembali materi } \\
\text { pelajaran yang telah dipelajari di } \\
\text { sekolah dengan budaya dan } \\
\text { dikehidupan disekitar saya }\end{array}$} & 6 & 18 & 3 & 1 & \multirow[t]{2}{*}{3,03} \\
\hline & & $21,42 \%$ & $64,28 \%$ & $10,71 \%$ & $3,57 \%$ & \\
\hline \multirow[t]{2}{*}{9} & \multirow{2}{*}{$\begin{array}{l}\text { Saya mempelajari terlebih dahulu } \\
\text { materi yang akan diajarkan dengan } \\
\text { budaya dan dikehidupan disekitar saya }\end{array}$} & 0 & 25 & 2 & 1 & \multirow[t]{2}{*}{2,85} \\
\hline & & $0 \%$ & $89,28 \%$ & $7,14 \%$ & $3,57 \%$ & \\
\hline \multirow[t]{4}{*}{10} & \multirow{2}{*}{$\begin{array}{l}\text { Saya belajar matematika sekedarnya } \\
\text { saja }\end{array}$} & 0 & 0 & 23 & 5 & \multirow[t]{2}{*}{1,82} \\
\hline & & $0 \%$ & $0 \%$ & $82,14 \%$ & $17,85 \%$ & \\
\hline & \multirow{2}{*}{ Rata-rata } & 1,6 & 13,6 & 5,8 & 7 & \multirow[t]{2}{*}{2,35} \\
\hline & & $5,71 \%$ & $48,57 \%$ & $20,71 \%$ & $25 \%$ & \\
\hline
\end{tabular}


Hasil analisis pada tabel 2 menunjukkan bahwa disposisi matematis pada aspek rasa percaya diri dalam pembelajaran matematika memperoleh nilai rata-rata skor 2,48 dengan kategori baik. Terdapat dua item dengan kategori kurang yaitu item tiga dan empat dengan rata-rata skor 1,89 dan 1,92. Hal ini menandakan bahwasanya siswa tidak setuju dengan pernyataan yang menyatakan bahwa mereka menyakini nilai matematika mereka tetap rendah meskipun elah belajar keras dan merasa malu diketahui orang lain jika memeroleh nilai jelek dalam matematika. Item dengan skor rata-rata tertinggi yaitu 3,03 tergolong kategori sangat baik. Pernyataan pada item tersebut menunjukn siswa merasa senang dan termotivasi dalam belajar matematika menggunakan pendekatan etnomatemtika.

Aspek selanjutnya kegigihan dan ketekunan dalam pembelajaran matematika. Tabel 3 menunjukkan bahwa aspek kegigihan dan ketekunan dalam pembelajaran matematika rata-rata skor 2,35 dan kategori baik. Item delapan memperoleh skor rata-rata 3,03 dengan ketegori sangat baik yang menunjukan bahwa siswa mengulangi kembali materi yang telah diperolehnya disekolah dan mengubungkannya dengan budaya dan kehidupn merek sehari. Hal tersebut disimpulkan banhwasanya pendekatan etnomatematika dapat membantu siswa untuk memahami dan mengingat konsep matematika yang telah diperolehnya.

Hasil penelitian mengungkapkan bahwa pada penerpan pendektan etnomatematika dapat meningkatkan disposisi matematis siswa terhadap pembelajaran matematika. Hal ini tersebut dapat meningkatkan berbagai kemampuan siswa dalam bidang matematika (Fouze \& Amit, 2018; Putra \& Indriani, 2017). Pemanfaatan budaya dan lingungan sekitar siswa memberikan pengaruh positif untuk dunia pendidikan yang membuat proses pembelajaran matematika menjadi lebih bervariasi dan menyenangkan sehingga berbagai kemampun siswa dibidang matematika (Amor et al., 2016). Hal ini dikarenakan budaya dan aktivits kehidupan sehari-hari sangat dikenal baik bukn hanya siswa melainkan guru dan bahkan masyarakan dunia. Selars dengn pernyatan yang mengungkapkan pendekatan etnomatematika tidak hanya dapat untuk memahami konsep matematika tetapi peserta didik juga dikenalkan, menyukai pelajaran matematika dan mencintai kebudayaan (Putra \& Indriani, 2017). Etnomatematika dapat menghasilkan keinginan dan minat baru, meningkatkan motivasi dan stimulasi kegiatan belajar, dan membawa efek positif terhadap psikologis pada siswa (Fouze \& Amit, 2018).

Sikap dan keyakinan siswa dalam menghadapi matematika dapat memengaruhi prestasi mereka dalam matematika. Disposisi sangat diperlukan dalam dunia pendidikan segingga siswa percaya diri dalam menghadapi masalah dengan pemikiran yang tinggi, mengembangkan kebiasaan baik dan memiliki pandangan positif tergdap matematika (Facione, Giancarlo, Noreen, \& Gainen, 2015). Oleh karenanya dalam setiap proses pembelajaran disertai dengan kesadaran dan dedikasi yang kuat dalam diri siswa dan para pendidik terkit dengan disposisi matematis.

Disposisi matematika siswa berkembang ketika mereka mempelajari aspek kompetensi matematis (Facione et al., 2015). Sebagai contoh, ketika siswa diberi persoalan matematika berkaitan dengn masalah kontekstual ataupun dengan budaya. Pendektan etnomatematika dapat membantu dalam menjelaskan konsep matematika, soal-soal cerita serta strategi yang memadai dalam pembelajaran matematika memungkinkan siswa mampu mengembangkan kemampuannya (Abdullah, 2017).

\section{Simpulan}

Berdasarkan hasil penelitian menunjukan bahwa pada penggunaan media komik pada pembelajaran matematika materi geometri, dapat memberikan pengaruh positif terhadap domain afektif siswa yaitu disposisi matematis. Hal ini terlihat berdasarkan hasil analisis data yang mengungkapkan bahwa pada setiap aspek disposisi matematis yang antara lain: 1) Rasa percaya diri dalam pembelajaran matematika; dan 2) kegigihan dan ketekunan dalam pembelajaran matematika, menunjukan bahwasanya siswa memberikan sikap atau respon positif terhadap masing-masing aspek. Sehingga disarankan kepada pendidik untuk memanfaatkan dan menerapkan pendekatan etnomatematika dalam pembelajaran matematika.

\section{Ucapan Terima Kasih}

Ucapan terima kasih yang merupakan bentuk apresiasi adanya kontribusi dari semua pihak yang telah membantu dalam keberlangsungan artikel ini. 


\section{Daftar Pustaka}

Abdullah, A. S. (2017). Ethnomathematics In Perspective Of Sundanese Culture. Journal on Mathematics Education, 8(1), 116.

Amor, D., Phys, J., Ser, C., Kusuma, D. A., Dewanto, S. P., \& Nurani, B. (2016). The role of ethnomathematics in West Java ( a preliminary analysis of case study in Cipatujah ). Journal of Physics: Conference Series PAPER, 3(2).

Ariawan, R., \& Nufus, H. (2017). Hubungan Kemampuan Pemecahan Masalah Matematis dengan Kemampuan Komunikasi Matematis Siswa. Jurnal THEOREMS (The Original Research of Mathematics), 1(2), 82-91.

Astuningtyas, E. L., Wulandari, A. A., \& Farahsanti, I. (2018). Etnomatematika Dan Pemecahan Masalah Kombinatorik. JURNAL MATH EDUCATOR NUSANTARA, 3(2), 59-134. https://doi.org/10.29407/jmen.v3i2.907

Facione, P. A., Giancarlo, C. A., Noreen, C., \& Gainen, J. (2015). The Disposition Toward Critical Thinking 1 by. Journal of General Education, 44(1), 1-17.

Farokhah, L., Arisetyawan, A., \& Jupri, A. (2017). The Effect Of Ethnomathematics-Based Savi ( Somatic , Auditory , Visualization, Intelectually ) Approach On Mathematical Communication Skill On Geometry In Elementary School. IJAEDU. International E-Journal of Advances in Education, III(9), 534-543.

Fouze, A. Q., \& Amit, M. (2018). Development of Mathematical Thinking through Integration of Ethnomathematic Folklore Game in Math Instruction. EURASIA Journal of Mathematics, Science and Technology Education, 14(2), $617-630$. https://doi.org/10.12973/ejmste/80626

Imswatama, A., \& Lukman, H. S. (2018). The Effectiveness of Mathematics Teaching Material Based on Ethnomathematics. International Journal of Trends in Mathematics Education Research, 1(1), 35-38. https://doi.org/10.33122/ijtmer.v1i1.11

Kusmaryono, I., \& Suyitno, H. (2016). The Role of Mathematical Representation and Disposition in Improving Students' Mathematical Power. AdMathEdu, 6(1).

Maryati, \& Pratiwi, W. (2019). Etnomatematika: eksplorasi dalam tarian tradisional pada pembukaan asian games 2018. Jurnal Pendidikan Matematika Dan Matematika, 5(1), 23-28.

Muhtadi, D., Sukirwan, Warsito, \& Prahmana, I. (2017). Sundanese Ethnomathematics: Mathematical Activities In Estimating, Measuring, And Making Patterns. Journal on Mathematics Education, 8(2), 185-198.

Nopriana, T. (2015). Disposisi Matematis Siswa Melalui Model Pembelajaran Geometri Van Hiele. Jurnal Pendidian Matematika Eु Matematika, 1(2), 80-94.

Nusantara, T., \& Rahardjo, S. (2017). Ethnomathematics In Arfak ( West Papua- Indonesia ): Numeracy Of Arfak. International Journal Of Scientific Eु Technology Research, 6(9), 325-327.

Permana, R., \& Adiansha, A. A. (2019). Membentuk Keterampilan Berpikir Kritis Matematis Siswa Melalui Model Brain Based Learning Ditinjau Dari Penalaran Induktif. JURNAL PENDIDIKAN MIPA, 9(1 SE-Articles). https://doi.org/10.37630/jpm.v9i1.177

Putra, R., \& Indriani, P. (2017). Implementasi Etnomatematika Berbasis Budaya Lokal dalam Pembelajaran Matematika pada Jenjang Sekolah Dasar. Jurnal Matematika Dan Pendidikan Matematika Vol., 1(1), $21-34$. https://doi.org/10.25217/jn.v1i1

Rattanatumma, T. (2016). Assessing the Effectiveness of STAD Model and Problem Based Learning in Mathematics Learning Achievement and Problem Solving Ability. Journal of Education and Practice, 7(12), 194-199.

Rostika, D., \& Junita, H. (2017). Peningkatan Kemampuan Pemecahan Masalah Siswa SD dalam Pemeblajaran Matematika dengan Model Diskursus Multy Representation (DMR). Jurnal Pendidkan Dasar, 9(1), 35-46.

Siniguian, T. M. (2017). Students Difficulty In Solving Mathematical Problems. International Journal of Advanced Research in Engineering and Applied Sciences, 6(2), 1-12.

Soraya, F., Cahyana, U., Sumantri, M. S., \& Adiansha, A. A. (2018). The Application of Realistic Mathematics Education ( RME ) Approach to Increase the Creative Thinking Ability of Fraction Subject Matter for Fourth-Graders of SDN Rawajati 06 Pagi. American Journal of Educational Research, 6(7), 1016-1020. https://doi.org/10.12691/education-6-719

Suharsono, S. (2015). Meningkatkan Kemampuan Pemahaman dan Disposisi Matematik Siswa Sma Menggunakan Teknik Probing Prompting. Edusentris, 2(3), 278. https://doi.org/10.17509/edusentris.v2i3.180 